DOI: $10.1515 /$ rpp-2017-0029

Doctor of Pedagogical Sciences, Full Professor, NATALYA BIDYUK

Khmelnytskyi National Univeristy

Address: 11 Instytutska St., Khmelnytskyi, 29016, Ukraine

E-mail: biduknm@ukr.net

$\mathrm{PhD}$ in Philological Sciences, Associate Professor, MARYNA IKONNIKOVA

Khmelnytskyi National Univeristy

Address: 11 Instytutska St., Khmelnytskyi, 29016, Ukraine

E-mail:ikonnikova@ukr.net

\title{
COMPARATIVE PEDAGOGICAL ANALYSIS OF PHILOLOGISTS' PROFESSIONAL TRAINING AT AMERICAN AND UKRAINIAN UNIVERSITIES
}

\begin{abstract}
The article deals with comparative and pedagogical analysis of philologists' professional training at American and Ukrainian universities on the conceptual (philosophical and pedagogical paradigms, concepts, theories, approaches, teaching goals and strategies), organizational and pedagogical (tuition fee, training duration and modes, entry requirements) and content and technological levels. The structures of philologists' professional training in the USA and Ukraine have been compared at the conceptual level. It has been revealed that at present, in both countries, professional training is carried out under the conditions of degree-based education taking into account competency-based, practice- and personalityoriented approaches, is based on the principles of humanization and humanitarization, learning democratization, the combination of national traditions and trends in the international educational space, is aimed at developing a modern, highly competitive specialist in philology. It has been indicated that in the system of philologists' professional training in the United States, there is an orientation towards the subject of learning; personal and practical approaches to organizing professional training of future philologists create the most favourable conditions for developing students' skills; however, in Ukraine these approaches are only becoming popular. It has been concluded that profound analysis of the advantages in using rational ideas of US experience will upgrade and improve the system of philologists' professional training in Ukraine, which is a component of continuing professional education caused by the concrete socioeconomic factors of society development and is to reveal the specificity of philologists' professional training (the content, forms, methods and pedagogical technologies), to create effective stimuli for professional and personal development of philologists.

Keywords: comparative pedagogical analysis, philology, philologist, professional training, university, the USA, Ukraine.
\end{abstract}

\section{INTRODUCTION}

The problem of professional training of specialists who are able to work effectively under the conditions of national and international competition, to combine high culture and fundamental knowledge with the ability to work in a team, to take organizational decisions at different levels of professional activity becomes extremely relevant in the context of restructuring political and economic structures in Ukrainian society. The success of the state in the global economic and cultural space depends on specialists' communicative competency, 
which, in turn, determines the necessity of training specialists who are fluent in a foreign language.

Reforming education in Ukraine, which is a part of the pan-European educational transformation, involves eliminating the disadvantages of the education system of previous years, one of which was the poor language training of specialists. Integration trends in education launched by the Bologna Process, which involve most European countries, enhance interest in studying the experience of education in other countries.

The US experience is useful for the national practice of philological education in the light of the following circumstances: first, Ukraine, like the USA, is a multicultural state that defines the features of language policy. Secondly, American higher education originated as degree-based, and bachelor's degree was the first one in this link. Thirdly, the United States has consistently accumulated leading world experience in the field of education, adapting it to the needs of the society. Over the past decades, foreign languages teaching in the United States has been characterized by the introduction of various organizational forms and methods that deserve attention in view of the need to improve professional philological training of Ukrainian professionals.

\section{THE AIM OF THE STUDY}

The aim of the study is to perform comparative pedagogical analysis of philologists' professional training at American and Ukrainian universities.

\section{THEORETICAL FRAMEWORK AND RESEARCH METHODS}

Over the past decades, Ukrainian scholars have actively pursued research on the problems of philologists' professional training in national and foreign experience. The peculiarities of American higher education have been considered by N. Bidyuk $(2013 ; 2016)$ (professional training of applied linguists), I. Biletska (2014) (the features of bilingual education in the USA); V. Kudin (2002) (the system of professional education); O. Maidan (2004) (pecularities of admission to American universities), O. Lishchinskyi (1995) (formation and development of the basic stage in the higher education systems of the USA and Ukraine), I. Pasynkova (2005) (the system of training Bachelors of Art in Philology at American Universities), O. Romanovskyi (1997) (the chronicle of American higher education), S. Shandruk (2013) (the system of secondary school teachers' training), O. Ya. Stoika (2015) (transformational processes in American higher education), I. Zvarych (2008) (assessment in American higher education institutions) et al.

A significant source for studying the US education system consists of the works by such American scholars as L. Bachman (1990), B. Bloom, M. Ginsburg \& R. Clift (1998), J. Goodlad (2007), D. Hymes, J. Pride \& J. Holmes (1972), E. John (2006), G. Madaus \& J. Hastings (1994), M. Smith (1999), R. Tyler (1949), H. Wasser (2007), L. Wolf-Wendel (2003) et al.

During our study we have used such methods as comparative analysis, generalization, systematization and individualization.

\section{RESULTS}

The system of higher education in the United States is not subject to the centralized public administration and is not state-owned. Local governments control and license educational institutions and programmes, whereas non-state institutions accredit and monitor quality. In contrast to the US higher education system, Ukrainian universities are subordinate to the Ministry of Education and Science, as well as relevant ministries (Bidyuk, 2013; 2016; Burdina, 2008; Leshchynskyi, 1995; Romanovskyi, 1997). It should be noted that reforming the education sector provides for decentralization of higher education management in the near future. 
In Ukraine, as in the United States, higher education can be obtained at state or private universities. An indisputable advantage of the American model of philologists' professional training at the institutional level is linguistic colleges aimed, first and foremost, at promoting career development of their graduates.

In the USA, tuition fee for a bachelor's degree in Philology ranges from 23 to 80 thousand dollars per year, in Ukraine $-8-28,5$ thousand gryvnias; for a master's degree from 30 to 120 thousand dollars in the USA; from 8,5 to 31 thousand gryvnias in Ukraine. Certainly, tuition fee in Ukrainian higher education institutions is much lower than in the United States, yet it does not correlate with the level of wages rates in the country. In addition, there is a system of student benefits and loans in the United States. Sponsoring and charitable organizations may also cover the costs of education. Due to the high tuition fees, in the United States there is a well-established system of equipping classrooms with the latest technologies (Maidan, 2004; Pasynkova, 2005; Shandruk, 2013). For example, at the University of Texas at Austin (2017), the department of Linguistics possesses research labs (phonetics lab, child language lab, signed language lab, linguistics department subject pool, computational linguistics lab, sound lab) so that students can develop their professional linguistic skills. Of our particular interest is the linguistics subject pool established in order to a) give students experience of taking part in experimental research and b) to help support ongoing research by the department's faculty and students. Thus, this program is designed to allow students to gain some familiarity with how some types of linguistics research are conducted (The University of Texas at Austin, 2017).

In Ukraine, higher education institutions are mostly financed by the state. As a result of a deep financial and economic crisis, classrooms are insufficiently equipped and modernized. However, Ukrainian universities strive to provide their students with the latest facilities needed for effective teaching and learning. At Khmelnytskyi National University, for instance, formation and development of students' foreign language professional competency are carried out in equipped lecture halls, educational classes, laboratories. All classrooms are provided with the necessary audio and video equipment, scientific and methodical literature, which allows effective conducting all types of classes using the latest information and computer technologies in teaching foreign languages. The library of the Department of Foreign Language Practice and Teaching Methodology has more than 2550 volumes of educational literature (dictionaries, textbooks, manuals). The fund of the department is equipped with the most up-to-date editions from publishing houses in Great Britain, the USA, Germany (Khmelnytskyi Natsionalnyi Universytet, 2017).

In the United States, professional training of philologists involves traditional (fulltime), distance (electronic) and combined modes, as well as ad hoc training, in Ukraine -fulltime, part-time and distance. Studying the US experience we can conclude that the most common modes of training are full-time and ad hoc training learning, in Ukraine - full-time and part-time (Kudin, 2002).

There are three academic degrees in the US higher education system, namely, a bachelor's degree (3-4 years), a master's degree (1-2 years) and $\mathrm{PhD}$ (5 years); in Ukraine, despite the adoption of the Law on Higher Education, there are four degrees, namely, a bachelor's degree ( 4 years), a master's degree (1,5-2 years), $\mathrm{PhD}(3-4$ years), doctoral degree (3 years). The academic year at US universities runs from the end of September to May and consists of three terms. In Ukraine, the academic year also lasts 9 months and is divided into two terms (Stoika, 2015). 
To enter a US university, one should undergo an open, competitive or selective admission process (a bachelor's degree), pass an entrance exam, the Miller analogies test (a master's degree) (John, 2006). For example, at Georgia State University, admission is based on a number of factors, depending upon level of entry and previous educational experience. Admission and placement decisions are made by the Office of Undergraduate Admissions using criteria approved by the University Senate and developed in accordance with policies of the Board of Regents of the University System of Georgia. Admission decisions are based on factors such as, but not limited to, an applicant's academic record, test scores, essay, letter of recommendation, circumstances, good conduct and character. Applications are reviewed and considered in the context of the overall applicant pool for the respective term. In Ukraine, to enter a higher education institution, one should pass the external testing (external independent evaluation), as well as pass the competition of certificates (Georgia State University, 2015-2016).

It should be noted that today in Ukraine the forms of the education process organization are lectures, tutorials, seminars, individual classes, all kinds of practices and consultations, independent study. Based on the research findings on the organization of the education process in the US system of higher education, philologists' training involves practically all types of educational activities implemented in the Ukrainian model of training lectures, seminars (discussions), practical classes, independent writing, etc. Given practical orientation of philologists'professional training in the USA, a significant amount of academic load includes practical classes, internship, practice (Ginsburg \& Clift, 1998).

In Ukraine, lectures and seminars prevail. We emphasize that the education process as American universities is less regulated than in Ukraine - the choice of training forms depends exclusively on personal preferences of the teacher. Some universities prefer lectures, others - seminars and practical classes. In addition, extra-curricular activities of philology students in the United States is more popular than in Ukraine. Perhaps, this is precisely the basis for improving the national system of higher education (Pasynkova, 2005).

We would like to pay special attention to linguistics tutorials implemented by Hardvard University. The tutorial program is designed to allow students to work individually or in small groups with faculty members and graduate students, to supplement the material covered in the required introductory courses, and to allow concentrators to investigate linguistic topics of particular interest to them. During the second year and the fall of the third year, concentrators take three small-group tutorials, each counting as a half course. Each half-course tutorial consists of two six-week units on a linguistic topic that complements the regular course offerings in the department; several such units are available at any given time. In the spring of the junior year, students take a half-course tutorial in which they meet with an individual faculty member to explore possible thesis topics or other areas of interest. The senior tutorial is usually restricted to honors candidates, who are expected to write a thesis demonstrating their ability to do sustained independent research in linguistics (Harvard University, 2017b).

In the context of personality- and practice-oriented approaches at American universities, of particular importance are active, creative teaching methods; research, case and project methods, discussions, business games, independent study (Burdina, 2008). In this aspect for Ukrainian system of philologists' training, where the student often acts as a passive product of the education process and traditional methods of the education process organization prevail, American educators' experience in using the forms and methods of philologists' professional training organization is on the agenda. 
The organization of the training content and the development of curricula and syllabi for professional training of philologists in the USA are determined primarily by the needs of the labour market, that is, carried out based on the principle of predictability (Goodlad, 2007; Smith, 1999; Tyler, 1949; Wasser, 2007). At Harvard University, the Department of Linguistics understands that undergraduates are interested in linguistics for a variety of reasons. Some plan to pursue graduate studies in linguistics or a related discipline; some plan to go on to professional work: and some see a concentration in Linguistics as interesting and valuable intellectually, but do not base their future vocational plans upon it. The Department has kept all of these considerations in mind in designing its course offerings and concentration requirements. Recent Harvard Linguistics concentrators have gone on to graduate school in linguistics, mathematics, computer science, cognitive science, English, and music; to medical school, law school, and business school; and into employment fields as diverse as editing, writing, translating, and language-processing software design (Harvard University, 2017a). In Ukraine, however, quite traditional is still narrow specialization.

A peculiarity of philological curricula in the United States is their variability and electivity (Hymes, Pride, Holmes, 1972). In Ukraine, academic courses are essentially mandatory, although within the framework of educational reforms taking place in our country, the principles of electivity are gradually being introduced in relation to curricula of specialists' professional training.

Based on the study of US experience, it has been concluded that, according to complaisance and consistency in mastering the content of curriculum, academic disciplines are divided into three groups: 1) those being studied necessarily in a strict sequence; 2) those being studied necessarily, however inconsistently; 3) those chosen by the student. Such an approach involves studying not in line with the scheme, as at most Ukrainian universities, but asynchronously, that is, without an obligatory distribution of the training content designated for academic years, normatively established terms of training, "permanent" academic groups, etc. According to the asynchronous approach, a new cycle of disciplines can be distinguished for students who are certified for all disciplines of an individual learning plan and wish to specialize in a particular field of knowledge with further writing a relevant thesis or for in-depth training in other disciplines.

In contrast to US higher education, where all disciplines are more closely related to specialization in a particular specialty, in Ukraine the cycles of fundamental, humanistic and socioeconomic disciplines are common to all specialties and areas of training, although they do not relate directly to professional interests of students. In Ukraine, individualization of philology curricula is on the agenda, and interuniversity mobility of students is virtually nonexistent due to the lack of such a need. Curricula are quite standardized, so there is no sense in going to another university since the content of curricula will be almost identical. Entry requirements for a master's degree are based on undergraduate academic achievements, and when choosing another university, students are to take exams or take an interview, which also reduces motivation toward academic mobility. Another problematic aspect is the lack of electives and the principles for regulating their optionality. Electives do not significantly individualize curricula. The number of those wishing to choose a course is limited, so sometimes the student has to attend a course that is quite "unpopular" without having neither the desire nor motivation to study it.

The results on analysis of the content of philology curricula and syllabi at American universities and professional linguistic colleges indicate that they are built on such an optional module system, which is clearly focused on professional success of graduates. Each academic year consists of a list of disciplines that can be replaced depending on the student's desire or the requirements of the labour market. At the same time, core professional courses, which are 
mandatory, allow the students to explore the subject area they have chosen. For comparison, at Ukrainian universities there is still no consensus on the content of mandatory courses. Quite important for reforming higher philological education in Ukraine is study and implementation of academic courses and programmes similar to those used at American universities, oriented toward global modern trends in development of philology and taking into account the needs of a future professional environment.

Most successful higher education institutions are responsible for assessing students' academic courses, since this factor significantly affects their place in university rankings (Bachman, 1990; Biletska, 2014; Bloom, Madaus, \& Hastings, 1994; Wolf-Wendel, 2003; Zvarych, 2008). In Ukraine, such a practice has not yet spread and the opinion of students, graduates do not play a role in forming the content of education. However, it is possible to predict the introduction of methodology for assessing courses in the national system of higher education.

\section{CONCLUSIONS}

So, comparative and pedagogical analysis of philologists' professional training at American and Ukrainian universities has been carried out on the conceptual (philosophical and pedagogical paradigms, concepts, theories, approaches, teaching goals and strategies), organizational and pedagogical (tuition fee, training duration and modes, entry requirements) and content and technological levels. Comparing the structures of philologists'professional training in the USA and Ukraine at the conceptual level, it has been revealed that at present, in both countries, professional training is carried out under the conditions of step-by-step education taking into account competency-based, practice- and personality-oriented approaches, is based on the principles of humanization, humanitarization, learning democratization, the combination of national traditions and trends in the international educational space, is aimed at developing a highly competitive specialist in philology. In the system of philologists' professional training in the United States, there is an orientation towards the subject of learning; personal and practical approaches to organizing professional training of future philologists create the most favourable conditions for developing students' skills; however, in Ukraine these approaches are only becoming popular.

In our opinion, profound analysis of the advantages ins using rational ideas of US experience will upgrade and improve the system of philologists' professional training in Ukraine, which is a component of continuing professional education caused by the concrete socioeconomic factors of society development and is to reveal the specificity of philologists' professional training (the content, forms, methods and pedagogical technologies), to create effective stimuli for professional and personal development of philologists.

Objective scientific analysis of US pedagogical achievements can become a valuable source for understanding progressive ideas about the process of forming a new strategy and development of the national system of philological education.

\section{REFERENCES}

1. Bachman, L. F. (1990). Fundamental considerations in language testing. Oxford: Oxford University Press.

2. Bidyuk, N. M. (2013). Kontseptualni zasady profesiinoi pidhotovky fakhivtsiv z prykladnoi linhvistyky u SSHAA. Porivnialna profesiina pedahohika, 2, 105-116.

3. Bidyuk, N. (2016). Higher education globalization in the context of American guidelines. Comparative Professional Pedagogy, 4, 7-14.

4. Biletska, I. (2014). Dvomovna osvita ta ii funktsionuvannia u SSHA. Molod $i$ rynok, 2, 104-108. 
5. Bloom, B. S., Madaus, G. P., \& Hastings, J. T. (1994). Evaluation to improve learning. New York: McGraw-Hill Book Company.

6. Burdina, S. V. (2008). Systema pidhotovky mahistriv upravlinnia osvitoiu u vyshchykh navchalnykh zakladakh SSHA. Dys. kand. ped. nauk. Luhanskyi Natsionalnyi Universytet imeniTarasa Shevchenka, Luhansk.

7. Georgia State University. (2015-2016). Undergraduate catalog. Retrieved from http://enrollment.gsu.edu/files/2015/03/undergraduate catalog 2015-2016.pdf.

8. Ginsburg, M. V., \& Clift, R. T. (1998). The hidden curriculum of the preserviceteacher education. New York: Houston.

9. Goodlad, J. (2007). Curriculum development. Boston: Baker.

10. Harvard University. (2017a). Department of Linguistics. Retrieved from https://linguistics.fas.harvard.edu/pages/why-linguistics.

11. Harvard University. (2017b). Tutorials. Retrieved from https://linguistics.fas. harvard.edu/pages/tutorials.

12. Hymes, D., Pride, J. B., \& Holmes, J. (1972). On communicative competence. Sociolinguistics. Harmondsworth: Penguin.

13. John, E. (2006). Education and the public interest: school reform, public finance, and access to higher education. Dordrecht: Springer.

14. Khmelnytskyi Natsionalnyi Universytet. (2017). Kafedra praktyky inozemnoi movy ta metodyky vykladannia. Vziato z http://www.khnu.km.ua/angl/.

15. Kudin, V. O. (2002). Profesiina osvita na riznykh etapakh liudskoi diialnosti. Profesiina osvita v zarubizhnykh krainakh: porivnyalnyi analiz, 11-45.

16. Leshchynskyi, A. P. (1995). Stanovlenie i razvitie bazisnogo etapa $v$ sistemakh vysshego obrazovaniia SShA $i$ Ukrainy. Dyss. kand. ped. nauk. Iuzhnoukrainskii pedagogicheskii universitet im. K.D.Ushinskogo, Odessa.

17. Maidan, O. V. (2004). Vyshcha osvita u SSHA: spetsyfika ta protses vstupu: dovidkove vydannia dlia studentiv i doslidnykiv. Kyiv: vydavnychyi dim "KM Akademiya".

18. Pasynkova, I. V. (2005). Systema pidhotovky bakalavriv humanitarnykh nauk z inozemnoi movy v universytetakh SSHA. Avtoref. dys. kand. ped. nauk. Instytut vyshchoi osvity Akademii pedahohichnykh nauk Ukrainy, Kyiv.

19. Romanovskyi, O. O. (1997). Khronika vyshchoi osvity SSHA (na prykladi diialnosti derzhavnykh i nederzhavnykh zakladiv). Kyiv.

20. Shandruk, S. I. (2013). Systema profesiinoi pidhotovky vchyteliv serednoi shkoly u Spoluchenykh Shtatakh Ameryky. Avtoref. dys. d-ra ped. nauk. Klasychnyi pryvatnyi universytet, Zaporizhzhia.

21. Smith, M. (1999). Curriculum theory and practice. New York: Routledge.

22. Stoika, O. Ya. (2015). Transformatsiini protsesy u vyshchii shkoli SSHA. Avtoref. dys. kand. ped. nauk. Ternopilskyi natsionalnyi pedahohichnyi universytet imeni Volodymyra Hnatyuka, Ternopil.

23. The University of Texas at Austin. (2017). Department of Linguistics. Retrieved from http://liberalarts.utexas.edu/linguistics/research-labs/index.php.

24. Tyler, R. W. (1949). Basic principles of curriculum and instruction. Chicago: University of Chicago Press.

25. Wasser, H. (2007). Higher education in Europe and the United States of America: diverse collection of essays. Lanham: University Press of America.

26. Wolf-Wendel, L. (2003). Two-body problem: dual-career-couple hiring policies in higher education. Baltimore; London: The Johns Hopkins University Press.

27. Zvarych, I. M. (2008). Pedahohichni zasady otsiniuvannia znan studentiv $u$ vyshchykh navchalnykh zakladakh SSHA. Avtoref. dys. kand. ped. nauk. Instytut pedahohiky Akademii pedahohihchnykh nauk Ukrainy, Kyiv. 